\title{
Factors affecting Bittern Botaurus stellaris distribution in a Mediterranean wetland
}

\author{
M. CLAUDIA ADAMO, LUCA PUGLISI and N. EMILIO BALDACCINI
}

\section{Summary}

The habitat requirements of a resident population of Bittern Botaurus stellaris were investigated during the breeding season in a Mediterranean upland wetland, with particular reference to the area's isolation from other wetlands, its small size and hydrological conditions. Vegetation structure and water-level were described and associated with booming male and nesting female distribution within the marsh. A logistic regression model showed that water-level was the only significant factor affecting the distribution of booming males, which occupied areas seasonally flooded with shallower water $(<1 \mathrm{~m})$. Females nested in seasonally flooded zones, while vegetation density appeared an important variable for nesting-site choice. Management of the wet area is discussed and the importance of a better understanding of the temporal dynamics of vegetation cover and spatial and temporal variations in water-level, and their possible effects on prey distribution, is highlighted.

\section{Introduction}

Despite the wide distribution of Bittern Botaurus stellaris in the nineteenth century, it has since declined in both range and population size, mostly because of land reclamation and human persecution (Day 1978, Day and Wilson 1978, Voisin 1991, Kushlan and Hafner 2000). More recently, West European populations have further declined due to various factors, including the inadequate management of potential or suitable sites, as in the United Kingdom (Bibby and Lunn 1982, Tyler et al. 1998). As a consequence, Bittern is listed in Annex I of Directive 79/409 of the European Union for Bird Conservation, and is therefore considered a high-priority species for conservation action.

Despite this, many aspects of its biology and ecology are not documented in detail, thus limiting the possibility of carrying out appropriate habitat management. In particular, detailed data on habitat requirements are almost completely lacking, since the only quantitative study compared features of sites occupied and unoccupied by booming males (Tyler et al. 1998), and no data on habitat selection within a site are available. Above all, no information is available on female nesting preferences (cf. Tucker and Evans 1997), which in this polygynous species may not coincide with locations of booming males (Gauckler and Kraus 1965). Furthermore, a better knowledge of the relationships between vegetation features and hydrological regime within the same site is needed to identify habitat characters selected by Bitterns, which are not highlighted when comparing different sites. 
Until recently, habitat management actions for Bitterns (e.g. Sutherland and Hill 1995, Hawke and Josè 1996) have been based on information gathered in countries covering a small part of the species' range and holding a small proportion of the whole population, while information on the East European and Mediterranean populations is almost totally lacking. In these countries, environmental, and particularly hydrological, conditions are markedly different from those of north-western Europe. Information from areas with contrasting characters is therefore needed to better understand the ecological needs of the species in the different parts of its range. In particular, Mediterranean and East European countries are characterized by summer droughts and frozen conditions in autumn-winter, in contrast to the less variable hydrological condition of north-western Europe.

The aims of this study were therefore to describe the habitat features of a Mediterranean upland marsh (Colfiorito, central Italy) and to evaluate whether booming males and nesting females selected parts of the marsh according to habitat features, in order to implement appropriate habitat management to improve Bittern conservation. Despite its isolation and its small size, the study area held a high density of resident Bitterns (about 1 booming male/10 ha), which settled in the area after 1991 when variations in the hydrological characteristics of the marsh were artificially induced (Puglisi 1997). These characteristics, such as areas of deep water and flooding, contrast with those of other Italian and western European marshes where breeding Bitterns are present.

\section{Study area}

Colfiorito marsh $\left(43^{\circ} \mathrm{O}^{\prime} \mathrm{N},{ }^{1} 2^{\circ} 52^{\prime} \mathrm{E}\right)$ is located at an altitude of $750 \mathrm{~m}$ a.s.l., on a plateau among the Apennines, Italy, and is isolated ( $>50 \mathrm{~km}$ away) from other wet areas. The wetland covers $c$. 86 ha, and is characterized by a high water-level $(40-160 \mathrm{~cm})$ in spring; water depth is up to $1 \mathrm{~m}$ higher in the rainy winters and usually $1 \mathrm{~m}$ lower in summer than in spring. The marsh freezes each winter for several weeks and snowfalls and freezing sometimes also occur during the reproductive period, as late as mid-April.

Vegetation is characterized by beds of reed Phragmites australis and less extensive areas of bulrush Schoenoplectus (Scirpus) lacustris, in an area crossed by a few ditches and scattered pools. Marginal stands of reed sweetgrass Glyceria maxima and reed canary grass Typhoides (Phalaris) arundinacea are also present (Figure 1).

The present layout was determined in 1991 by artificially raising the waterlevel. Since then, no management action has been carried out on the vegetation, apart from the creation of some open-water areas by reed-cutting in 1997, which have not yet been re-colonized by vegetation.

\section{Methods}

\section{Monitoring the Bittern population}

Booming males were censused three times each year in 1996, 1997 and 2000, between late March and mid-May, and ten times between February and June 2001. All the booming males were approached by canoe as close as possible 


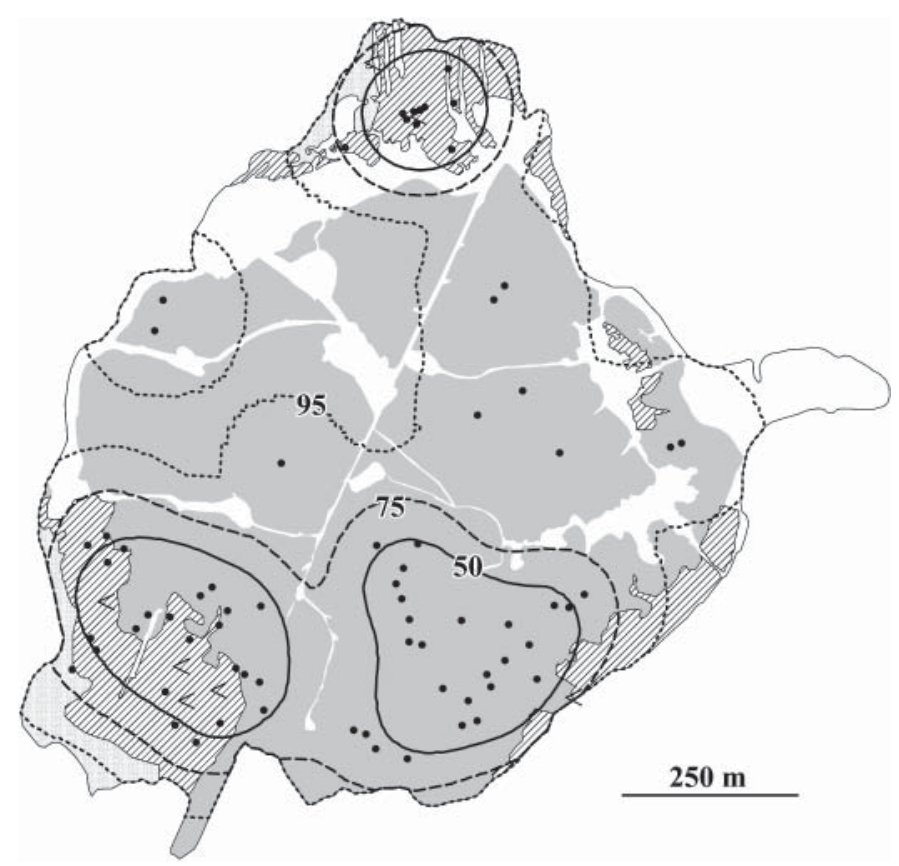

Figure 1. Booming male Bittern locations (black dots) and position of the seven nests located during the 2001 season (black stars) at Colfiorito marsh, Italy. The areas with $50 \%$, $75 \%$ and $95 \%$ probability of presence (continuous, broken and dotted lines, respectively), computed by means of Kernel analysis, are indicated. Dark dotted areas, reedbeds; hatched areas, bulrush stands; light dotted areas, mixed stands of Typhoides arundinacea and Glyceria maxima.

(5-100 $\mathrm{m})$, and their position, estimated by triangulation using GPS and a compass (minimum accuracy $8.5 \mathrm{~m}$ ), was plotted on a 1:2,000 map. Birds were located during daylight hours and their total number was further checked during the peak of booming activity at dawn or dusk.

Possible flight displacements over the whole marsh were monitored and mapped from the surrounding hills in 1996 and 2000-2001 from late April until the end of the breeding season during two to five sessions each week, each one lasting 4-6 hrs. Displacements were mapped and the nests of females making feeding flights were all located and, when possible, visited.

\section{Relationships between habitat features and Bittern distribution}

A geographic information system was prepared with the MapInfo package, gathering information on vegetation distribution from aerial photographs (1994 and 1997) from the Istituto Geografico Militare Italiano, implemented by data measured directly in the field and georeferred by means of a GPS (Garmin $12 \mathrm{XL}$ ). In particular, water-depth isolines were computed (Inverse Distance Weighted method) starting from 221 measures taken inside vegetation stands in 2001, corrected for temporal variations of flooding conditions measured weekly at three control points. 
In order to analyse possible habitat preferences by males, we sampled 16 locations where booming males occurred during two mid-season census days in 2001 (presence plots), and 16 locations randomly chosen outside a $30 \mathrm{~m}$ buffer area plotted around all the locations of booming males (absence plots) and therefore external to $75 \%$ Kernel contours (see below). Habitat features at each location were described by measuring three points within a $25 \mathrm{~m}$ radius plot.

In order to analyse possible habitat preferences by nesting females, we sampled six plots centred on nest platforms found in 2001 (all located in bulrush) and nine plots randomly chosen in bulrush beds. At each nesting place, vegetation was sampled in a square centred on the nest and at three adjacent points $2 \mathrm{~m}$ away in order to test for microhabitat selection; at each control plot, habitat measures were made at three points, within a $2 \mathrm{~m}$ radius. At each of 147 points, the number of young or old stems of each plant species, the height of vegetation stands and the diameter at $1 \mathrm{~m}$ from the ground of 10 randomly chosen stems of each species, and the water depth (mean of three measurements) were measured within a $0.7 \mathrm{~m}$ square. Vegetation was sampled between 2 and 21 July 2001, to avoid disturbing breeding birds.

\section{Relationships between Bittern distribution and environmental factors}

The area used on the whole by male Bitterns was estimated by fixed Kernel analysis, using the Least Square Cross Validation method to calculate the smoothing factor (Seaman et al. 1999). To determine whether birds used different vegetation types in proportion to their availability, a chi-square test between the extent of each vegetation type within Kernel contours and its total amount over the whole wet area was carried out.

In order to evaluate the main environmental factors affecting the position of booming males as a whole in the area, a multivariate model of Bittern presence was computed using logistic regression. The dependent categorical variable was the presence or absence of Bitterns within the plot, while the number of young and old stems (not distinguishing between Phragmites and Schoenoplectus since Bitterns were found in pure beds of both species), stem diameter and water depth were the independent variables. The variables were selected by means of a backward selection procedure based on a maximum likelihood method, to determine those to be removed from the model: the log-likelihood of the model containing all independent variables was compared with that of a model which dropped one of them; when significance (likelihood ratio test) was >0.05, the variable was removed from the model. The goodness of fit of the model was assessed by comparing the predicted with the observed value in a $2 \times$ 2 classification table, determining the percentage of correctly classified locations.

Habitat preferences of nesting females were evaluated at a macrohabitat level by comparing each variable for the areas with and without nests by $t$-test. Microhabitat differences between nesting sites were searched for with one-way ANOVA for repeated measures (within subjects), comparing measurement at the nest point with measurements at $2 \mathrm{~m}$ from the nest in the northerly, south-easterly and south-westerly directions.

Distances of each nest from the nearest open water and from the marsh edge were also included as variables in the macrohabitat analysis. Water depth was 
transformed by means of Box-Cox transformation $(\lambda=1.5)$ to meet the assumption of normality for the $t$-test, and then the reliability of the sample's estimate was reported transforming the confidence limits back to linear scale (Sokal and Rohlf 1995). The available data were too few to compute a logistic regression model. In the case of repeated tests, the significance level was adjusted by means of the Bonferroni method (Sokal and Rohlf 1995).

\section{Results}

Males

The number of booming males counted on each census day in the years 1996, 1997 and 2000 remained stable (eight individuals), continued at this level between mid-February and early May 2001, and then rapidly decreased. In total, 70 locations over 10 census days were recorded in 2001.

Distribution of males within the marsh was not uniform in any one year: in 2001, Kernel analysis showed that the contour region extended over 16 ha divided into three nuclei with $50 \%$ of locations, over 29 ha in two nuclei with $75 \%$, and over 58 ha in two nuclei with 95\% (Figure 1). The largest $75 \%$ Kernel nucleus in the southern part of the marsh was generated by the presence of seven males, while the second $75 \%$ nucleus held one male only. This distribution coincided with what was found in previous years (e.g. 14 of 24 locations in 1996, 12 of 24 in 1997 and 15 of 24 in 2000 within the $50 \%$ Kernel contour of 2001).

\section{Females}

The number of females performing feeding flights (more than four observations throughout the breeding season) was different between years: one in 1996, one in 2000 and seven in 2001. A total of ten nests were identified: one in 1996, two in 2000 and seven in 2001. For one nest in 2000, we observed a female feeding her young without flight displacements. All the nests were located in bulrush beds (Figure 1).

\section{Vegetation characters and water depth}

The mean stem diameter in reedbeds was $8.9 \mathrm{~mm}( \pm 2.0$; mean \pm S.D.; $n=815)$ for old stems, and $8.3 \mathrm{~mm}( \pm 2.3 ; n=801)$ for young ones, with an average height of $3.5 \mathrm{~m}( \pm 0.6 ; n=87)$. Reedbed density, measured in plots of pure Phragmites, was 199.8 stems $/ \mathrm{m}^{2}( \pm 63.4, n=63)$; the young/old stem ratio was 0.33 ( \pm 0.15$)$. Mean diameter of bulrush stems was $8.9 \mathrm{~mm}( \pm 2.6 ; n=579)$ for old stems and $9.5 \mathrm{~mm}$ $( \pm 2.7 ; n=616)$ for young ones, with an average height of $3.0 \mathrm{~m}( \pm 0.5 ; n=65)$. Density of pure bulrush plots was 271 stems $/ \mathrm{m}^{2}( \pm 105.4, n=33)$; the young/old stem ratio was 1.35 ( \pm 0.82$)$.

Water-levels during the breeding season were similar in all the study years, and seasonal variation was comparable. As an example, in 2001 the water-level remained stable between mid-February and late May (difference between minimum and maximum level $11 \mathrm{~cm})$ then progressively lowered $(-30 \mathrm{~cm}$ at mid-June, $-50 \mathrm{~cm}$ at mid-July, $-100 \mathrm{~cm}$ at mid-August, with respect to the spring 


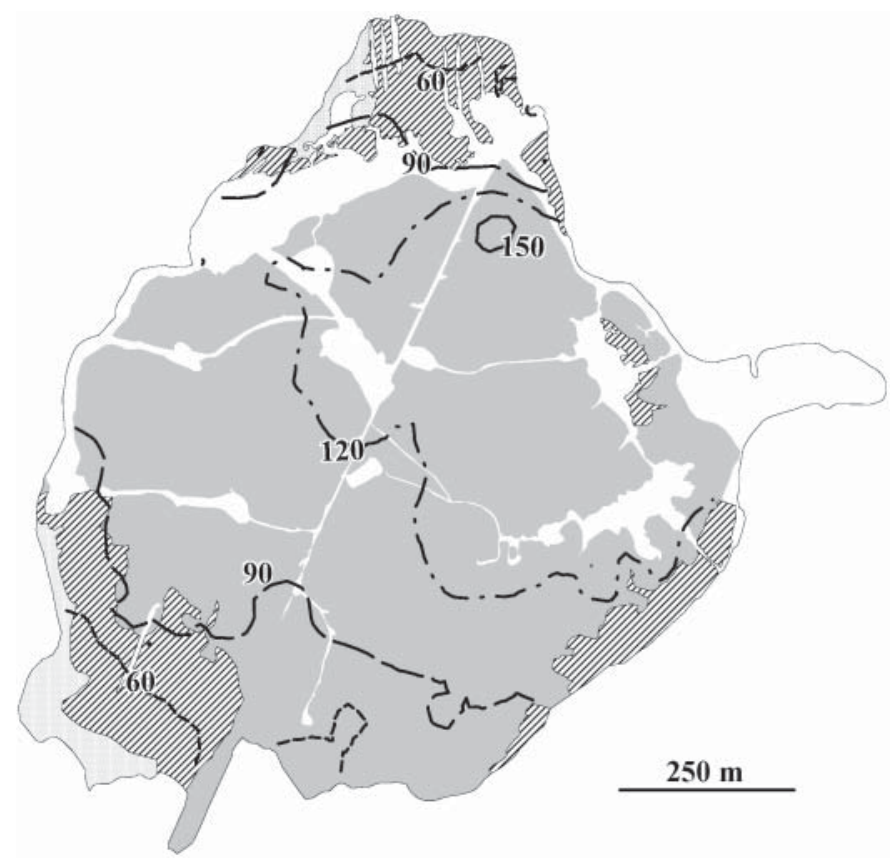

Figure 2. Spring flooding level at Colfiorito marsh, Italy. The isobaths with the corresponding depth values $(\mathrm{cm})$ are shown.

level). During the reproductive period, water depth was above $30 \mathrm{~cm}$ throughout the study site, exceeding $90 \mathrm{~cm}$ in 47 ha of the marsh (Figure 2). Given the yearly water-level fluctuations, the extent of flooded vegetation stands decreased to 40 ha in summer, with a water-level deeper than $30 \mathrm{~cm}$ in 8 ha only.

\section{Relationships between Bittern distribution and environmental factors}

The proportion of each vegetation type within Kernel contours for male Bitterns did not differ from the total available extent within the wet area (Table 1). For each measured variable the mean value and standard deviation in occupied and unoccupied areas are reported in Table 2. The logistic regression model identified only water depth as a predictive variable for the presence of male

Table 1. Extent (ha) of vegetation stands dominated by the indicated plant species within each contour identified by the Kernel analysis of male booming Bittern distribution, and within the whole wet area of Colfiorito marsh, Italy.

\begin{tabular}{lllccc}
\hline Kernel contours & Ph. australis & G. maxima-T. arundinacea & S. lacustris & $\chi^{2}$ & $P$ \\
\hline $50 \%$ & 10.75 & 0 & 5.02 & 2.45 & $\mathrm{~ns}$ \\
$75 \%$ & 20.39 & 0.53 & 8.75 & 2.82 & $\mathrm{~ns}$ \\
$95 \%$ & 45.44 & 1.65 & 10.83 & 0.03 & $\mathrm{~ns}$ \\
Wet area & 55.13 & 1.98 & 12.36 & & \\
\hline
\end{tabular}

For each contour, the proportion of each habitat was compared with its total availability, reported in the last row, by means of the $\chi^{2}$ test. 
Table 2. Mean value ( \pm S.D.) of each environmental variable measured in plots occupied and unoccupied by booming bittern males at Colfiorito marsh, Italy ( $n=16$ for both groups).

\begin{tabular}{lcc}
\hline & Occupied & Unoccupied \\
\hline Water depth $(\mathrm{cm})$ & $87.3 \pm 25$ & $118 \pm 18.3$ \\
Stem diameter $(\mathrm{mm})$ & $8.8 \pm 0.8$ & $9 \pm 1.8$ \\
Old stem density $\left(n / 0.49 \mathrm{~m}^{2}\right)$ & $73.9 \pm 24.2$ & $71.2 \pm 19.8$ \\
Young stem density $\left(n / 0.49 \mathrm{~m}^{2}\right)$ & $45.6 \pm 29.9$ & $22.4 \pm 6.9$ \\
\hline
\end{tabular}

Table 3. Result of logistic regression. The only variable present in the final model after the selection procedure is shown.

\begin{tabular}{lllll}
\hline Variables & $B$ & S.E. & $t$ & $P$ \\
\hline Water depth & -0.06 & 0.02 & -2.79 & $<0.01$ \\
Constant & 6.6 & 2.5 & 2.7 & $<0.01$ \\
\hline
\end{tabular}

$B$, standardized coefficient.

Bitterns in 2001, which was negatively affected by increasing water-levels (Table 3). The model, accounting for about $44 \%$ of the variance of the dependent variable (Nagelkerke's $R^{2}$ ), correctly classified $84.4 \%$ of all cases.

The environmental characteristics of nesting areas of females, referring to the larger 2001 sample only, were similar to those of other randomly selected plots within bulrush beds with regard to stem diameter, water depth and position relative to the marsh edge or to open water, while stem density tended to be lower at nest plots (Table 4). At a microhabitat level, contrast analysis across repeated measures of nesting site environmental variables, showed that bulrush density differed between each nest spot and adjacent measured spots (Table 5).

Table 4. Mean value $( \pm$ S.D.) of each variable measured at six Bittern nests and at nine control plots, at Colfiorito marsh, Italy, compared with $t$-tests.

\begin{tabular}{lccrr}
\hline & Occupied & Unoccupied & $t$ & $P$ \\
\hline Water depth $(\mathrm{cm})$ & $72.1 \pm 34$ & $75.7 \pm 44.5$ & 0.3 & $\mathrm{~ns}$ \\
Stem diameter $(\mathrm{mm})$ & $9.4 \pm 1.8$ & $9.0 \pm 2.2$ & -0.3 & $\mathrm{~ns}$ \\
Bulrush density $\left(n / 0.49 \mathrm{~m}^{2}\right)$ & $86.3 \pm 28$ & $135 \pm 50.6$ & 2.1 & $\mathrm{~ns}$ \\
Distance from open water $(\mathrm{m})$ & $62.2 \pm 46.2$ & $32.7 \pm 34.8$ & -1.4 & $\mathrm{~ns}$ \\
Distance from marsh edge $(\mathrm{m})$ & $94.2 \pm 39$ & $56.7 \pm 45$ & -1.7 & $\mathrm{~ns}$ \\
\hline
\end{tabular}

Table 5 . Mean value ( \pm S.D.) for each variable of six nesting plots at Colfiorito marsh, Italy, measured at the nest point (1) and its neighbourhood (2-3-4), and compared with contrast analysis.

\begin{tabular}{lcccccc}
\hline & 1 & 2 & 3 & 4 & $F(1 ; 5)$ & $P$ \\
\hline Water depth $(\mathrm{cm})$ & $68.7 \pm 14.5$ & $76.8 \pm 21.3$ & $69.2 \pm 15.7$ & $67.7 \pm 17.2$ & 3.2 & $\mathrm{~ns}$ \\
$\begin{array}{l}\text { Stem diameter }(\mathrm{mm}) \\
\begin{array}{l}\text { Bulrush density } \\
\left(n / 0.49 \mathrm{~m}^{2}\right)\end{array}\end{array}$ & $9.4 \pm 1.7$ & $9.8 \pm 1.9$ & $9.4 \pm 1.4$ & $9.0 \pm 2.2$ & 0.003 & $\mathrm{~ns}$ \\
$\begin{array}{l}\text { Old bulrush density } \\
\left(n / \mathrm{o} / 49 \mathrm{~m}^{2}\right)\end{array}$ & $182.9 \pm 102.2$ & $66.0 \pm 46.0$ & $73.8 \pm 39.4$ & $96.6 \pm 57.9$ & 11.2 & $\mathrm{~ns}$ \\
$\begin{array}{l}\text { Young bulrush density } \\
\left(n / 0.49 \mathrm{~m}^{2}\right)\end{array}$ & $227.5 \pm 91.3$ & $85.4 \pm 72.3$ & $93.9 \pm 28.9$ & $112.9 \pm 69.5$ & 17.6 & 0.009 \\
\hline
\end{tabular}


Table 6. Characters of feeding flights of the five female Bitterns observed more than ten times at Colfiorito marsh, Italy.

\begin{tabular}{lllllll}
\hline Female & Observed flights $(n)$ & Average distance \pm S.D. & \multicolumn{2}{l}{ Kernel contour } & \multirow{2}{*}{ External areas } \\
\cline { 5 - 6 } & & & C50 & C75 & C95 & \\
\hline 1 & 48 & $451.2 \pm 195 \cdot 7$ & - & - & - & 0 \\
2 & 15 & $259.0 \pm 319.4$ & 4 & 4 & 2 & 5 \\
3 & 11 & $103.0 \pm 33.4$ & 9 & 1 & 1 & 0 \\
4 & 21 & $335.6 \pm 332.7$ & 11 & 2 & 5 & 3 \\
5 & 12 & $168.4 \pm 137.1$ & 0 & 3 & 8 & 1 \\
\hline
\end{tabular}

For each individual, the number of observations, the mean distance travelled $(\mathrm{m})$ and the number of locations within the $50 \%, 75 \%$ or $95 \%$ contours identified by the Kernel analysis of male distribution (for females 2-5, observed in 2001), or in grass-fields outside the marsh, are reported.

Female nesting areas appeared to overlap those occupied by males: in 2001, five nests were within the $50 \%$ Kernel contour of male distribution and the other two within the $75 \%$ contour. The number of feeding flights varied between females and only five of them (one in 2000 and four in 2001) achieved more than ten observations; in particular, a female nesting in a 0.4 ha marginal area in 2000 was observed the most. Foraging areas of females observed in 2001 were included in those occupied by booming males or located in seasonally flooded external grass-fields (Table 6). In all, 51\% of feeding locations were in areas with a water depth below $90 \mathrm{~cm}, 32 \%$ in water depth above $90 \mathrm{~cm}$ and $17 \%$ in areas external to the marsh.

\section{Discussion}

Males

A breeding Bittern population settled in the Colfiorito marsh soon after waterlevels were artificially raised in 1991. In less than 5 years the population reached eight booming males, and remained stable afterwards. Density (about 9.3 booming males/10o ha) was very high compared with that reported in the literature (0.9-5.5: Cramp and Simmons 1977, Puglisi et al. 1995, Dvorak et al. 1997, Hagemeijer and Blair 1997, Kayser et al. 1998, Piskorski 1999).

The number and temporal distribution of locations obtained allowed a good general estimation of their distribution within the marsh. Indeed, although the Colfiorito marsh covers only 86 ha, Bitterns were unevenly distributed within the wet area, being concentrated ( $75 \%$ of locations) in two distinct, unbalanced nuclei covering no more than $30 \%$ of the whole marsh (about 30 ha). Such a distribution pattern was noticed in all the study years and in particular was certainly maintained during the whole booming season in 2001. The factors responsible for this distribution pattern may be of a social character (e.g. the need to display in a common area) but, given the small size of the site, the distance between the two nuclei and the far carrying capacity of male Bittern vocalizations, more probably they are of an environmental nature. Male distribution appeared not to be bound to a particular vegetation-cover type, and the logistic regression model excluded all the considered parameters relative to vegetation structure. Instead water-level proved the only significant factor 
affecting the distribution of booming Bitterns within the marsh. Males were found in areas with a water-level lower than $1 \mathrm{~m}$ that dry up in summer.

Correlations between hydrological conditions and bird distribution have been found in other herons (e.g. Krebs 1974, Kushlan 1976, 1981, Strong et al. 1997). In particular, seasonally flooded habitats may provide good ecological conditions for fish and invertebrates both for feeding and for breeding (Poizat and Crivelli 1997 and references therein), possibly constituting spots of great opportunity for food-gathering.

\section{Females}

This study is the first describing quantitatively the nesting habitat of Bittern. Gauckler and Kraus (1965) provided a general description based on 17 nests, found in cattail (Typha spp.) or reed-dominated stands growing in water 5-60 cm deep. At Colfiorito, nests were found only within bulrush stands, but it cannot be excluded that females also bred in reedbeds. The absence of observations in reedbeds may be due to various and opposite causes: absence of nests; females nesting but not performing feeding flights; or early failure of the nests. Bulrush beds grow in water less than $1 \mathrm{~m}$ deep: whether females select for a particular vegetation type or for the lowest water-level is impossible to discriminate, as the two factors vary together at our study site. Within Schoenoplectus beds, females built their nest on denser vegetation thickets, within apparently less dense patches: the less tight vegetation stands may facilitate circulation of prey among stems, while the more covered parts appear favourable for sheltering the nests.

At Colfiorito, female Bitterns did not perform feeding flights every year: for example seven females flew in 2001, while just one did so in 2000. The feeding displacements we observed in 2001 were coincident with a low reproductive success (Puglisi and Bretagnolle, unpublished data), apparently due to chick starvation, possibly indicating that females were forced to move relatively far from the nest to search for patches richer in prey. Female Bitterns can catch food directly from the nest (Adamo 2002) and the proximity of nesting and feeding areas could be a strong prerequisite for achieving an optimal time budgeting of reproductive activities and a potentially high reproductive success.

\section{Wet area management}

Until recently, much attention has been paid to reedbeds as Bittern habitat, probably because of their wider availability in Western Europe. In fact, throughout the species range, Bitterns are found in marshy areas of tall grasses such as reed, cattails, rushes (Scirpus spp., Schoenoplectus lacustris, etc.) (Bauer and Glutz von Blotzheim 1966, Cramp and Simmons 1977, Hancock and Kushlan 1984), as well as rice-fields (Puglisi et al. 1997) but also in willow shrubs (Dement'ev and Gladkov 1951). The absence of a preference for a particular cover type, namely for reeds, was also observed at Colfiorito, thus suggesting that features of the vegetation cover other than the dominating species could influence Bittern presence. The vegetation cover at the study site appeared on the whole suitable, without marked differences between occupied and unoccupied areas at least by booming males, while local variations were particularly favourable for nesting 
females. Reed density was comparable to that reported in other studies, but stems were larger and taller (cf. Hawke and Josè 1996, Graveland 1998, Adams and Bate 1999, Barbraud et al. 2002). In fact, the reed of Colfiorito can be defined as "vigorous", according to the classification of reedbed health given by EUREED (Van der Putten 1997). It is worth noting that such strong stems allow Bitterns to move and perch well above the water-level.

Reedbeds and bulrush-beds differed in their ratio of young to old stems, which apparently resulted in different patterns in the two vegetation covers. A monitoring programme should thus be undertaken to verify whether in the future vegetation cover will evolve towards a less suitable structure.

The water-level is much higher at the study site than that generally considered as suitable for Bittern (Hagemeijer and Blair 1997, Sinnasamy and Mauchamp 200o). Spatial and temporal variations in water depth at Colfiorito marsh determine the distribution of booming males and, probably, nesting females during the reproductive season. Some of the areas unexploited during breeding are likely to be used later during summer as the marsh dries out and they remain the only wet areas. Water-level appeared to be the main factor affecting Bittern distribution within the marsh: water depth per se appears not to be important, since Bitterns are found throughout their range in areas with various flooding levels, but water depth presumably has an impact through its effect on prey availability and vegetation structure.

The specific correlation between the hydrological cycle and Bittern response may differ among areas, and an optimal marsh layout probably cannot be described. For example, at Colfiorito, Bitterns settled and reached a high density soon after water-levels were raised. This last action, however, cannot be considered of general validity because often it causes a reduction in vegetation cover.

In general, the interaction between vegetation cover and water-level and its variation, as factors determining prey abundance, distribution and accessibility, should be carefully evaluated in order to plan management actions for Bittern. At the Colfiorito marsh, for example, we think it inadvisable currently to effect any direct intervention, such as cutting vegetation. In fact, given the vegetation density, its renovation rate, the low re-colonization rate of mown areas and the small extent of wet area, it seems likely that the effect of wind, winter freezing and annual water-level variations will suffice in maintaining the present wetland setting. In fact, it appears very important to maintain high winter and spring water-levels and the consequent summer fluctuations.

\section{Acknowledgements}

We would like to thank the Ente Parco Regionale di Colfiorito; Giulio Cagnucci and Francesco Renzini for their valuable support in loco; and the Colfiorito Bittern-team, F. Brachini, A. Franceschi, E. Giannetti and F. Sarti, who helped us in the field.

\section{References}

Adamo, M. C. (2002) Il tarabuso ed il suo habitat: riflessi sul comportamento spaziale e riproduttivo. PhD thesis, University of Pisa. 
Adams, J. B. and Bate, G. C. (1999) Growth and photosynthetic performance of Phragmites australis in estuarine waters: a field and experimental evaluation. Aquat. Bot. 64: 359-367.

Barbraud, C., Lepley, M., Mathevet, R. and Mauchamp, A. (2002) Reedbed selection and colony size of breeding Purple Herons Ardea purpurea in southern France. Ibis 144: 227-235.

Bauer, K.M. and Glutz von Blotzheim, U. (1966) Handbuch der Vögel Mitteleuropas, vol. I. Frankfurt am Main: Akademische Verlagsgesellschaft.

Bibby, C. J. and Lunn, J. (1982) Conservation of reed beds and their avifauna in England and Wales. Biol. Conserv. 23: 167-186.

Butler, R. W. (1993) Time of breeding in relation to food availability of female Great Blue Herons (Ardea herodias). Auk 110: 693-701.

Cramp, S. and Simmons, K. (eds.) (1977) The birds of the western Palearctic, vol. I. Oxford: Oxford University Press.

Custer, T. W., Hines, R. K. and Custer, C. M. (1996) Nest initiation and clutch size of Great Blue Herons on the Mississippi river in relation to the 1993 flood. Condor 98: 181-188.

Daan, S., Dijkstra, C., Drent, R. and Meijer, T. (1988) Food supply and the annual timing of avian reproduction. Pp. 392-407 in Ouellet, H., ed. Acta XIX Congressus Internationalis Ornithologici, vol. 1. Ottawa: National Museum of Natural Sciences, University of Ottawa Press.

Day, J. C. U. (1978) The bittern's fading boom. Country Life 1176-1177.

Day, J. C. U. and Wilson, J. (1978) Breeding bitterns in Britain. Br. Birds 71: 285-300.

Dement'ev, G. P. and Gladkov, N. A. (1951) Birds of the Soviet Union, vol. 2. Israel Program for Scientific Translations (English translation 1969).

Dvorak, M., Nemeth, E., Tebbich, S., Rössler, M. and Buse, K. (1997) Verbreitung, Bestand und Habitatwahl schilfbewohnender Vogelarten in der Naturzone des National parks Neusiedler See-Seewinkel. Biologisches Forschungsinstitut für Burgerland. Report no.86.

Gauckler, A. and Kraus M. (1965) Zur brutbiologie der Grossen Rohrdommel (Botaurus stellaris). Vogelwarte 86: 129-146.

Graveland, J. (1998) Reed die-back, water level management and the decline of the Great Reed Warbler Acrocephalus arundinaceus in The Netherlands. Ardea 86: 187-201.

Hagemeijer, E. J. M. and Blair, M. J. (eds.) (1997) The EBCC atlas of European breeding birds, their distribution and abundance. London: Poyser.

Hancock J. and Kushlan J. A. (1984) The Herons handbook. London: Croom Helm, and New York: Harper and Row.

Hawke, C. J. and Josè, P. V. (1996) Reedbed management for commercial and wildlife interest. Sandy, U.K.: RSPB.

Kayser, Y., Hafner, H. and Massez, G. (1998) Dénombrement des mâles chanteurs de Butors étoilés Botaurus stellaris en Camargue en 1996. Alauda 66: 97-102.

Krebs, J. R. (1974) Colonial nesting and social feeding as strategies for exploiting food resources in the Great Blue Heron (Ardea herodias). Behaviour 51: 99-134.

Kushlan, J. A. (1976) Wading bird predation in a seasonally fluctuating pond. Auk 93: $467-476$.

Kushlan, J. A. (1981) Resource use strategies of wading birds. Wilson Bull. 93: 145-163.

Kushlan, J. A. and Hafner, H. (2000) Heron conservation. London: Academic Press.

Lombardini, K., Bennetts, R. and Tourenq, C. (2001) Foraging success and foraging habitat use by Cattle Egrets and Little Egrets in the Camargue, France. Condor 103: 38-44.

Piskorski, M. (1999) Rozmieszczenie, liczebnosc i ochrona baka Botaurus stellaris na Pojezierzu Leczynsko-Wlodawskim. Chronmy Przyr. Ojczysta 55: 52-64.

Poizat, G. and Crivelli, A. J. (1997) Use of seasonally flooded marshes by fish in a Mediterranean wetland: timing and demographic consequences. J. Fish Biol. 51: 106-119.

Puglisi, L. (1997) Tarabuso. P 78 in Magrini M. and Gambaro C., eds. Atlante ornitologico dell'Umbria. Regione dell'Umbria. 
Puglisi, L., Fontanelli, A., Perfetti, A. and Taverni, M. (1995) The population of Bittern Botaurus stellaris in the Diaccia Botrona marsh (Central Italy): four years of census (1991-94). Avocetta 19: 185-189.

Puglisi, L., Perfetti, A. and Alessandria, G. (1997) Risultati del censimento di Tarabuso Botaurus stellaris nidificante in Piemonte e Toscana: 1995-96. Avocetta 21: 134.

Seaman, D. E., Millispaugh, J. J., Kernohan, B. J., Brundge, G. C., Raedeke, K. J. and Gitzen, R. A. (1999) Effects of sample size on Kernel home range estimates. J. Wildl. Mgmt. 63: 739-747.

Sinnasamy, J. M. and Mauchamp, A. (2000) Roselières: gestion fonctionelle et patrimoniale. ATEN edit., Fondation EDF, Réserves Naturelles de France \& Station Biologique de la Tour du Valat publ., Cahiers Techniques 63: 1-96.

Sokal, R. R. and Rohlf, F. J. (1995) Biometry. New York: W. H. Freeman.

Strong, A. M., Bancroft, G. T. and Jewell, S. D. (1997) Hydrological constraints on Tricolored Heron and Snowy Egret resource use. Condor 99: 894-905.

Sutherland, W. J. and Hill, D. A. (1995) Managing habitat for conservation. Cambridge, U.K.: Cambridge University Press.

Tucker, G. M. and Evans, M. I. (1997) Habitats for birds in Europe: a conservation strategy for the wider environment. Cambridge, U. K.: BirdLife International (BirdLife Conservation Series no. 6).

Tyler, G., Smith, K. W. and Burges, D. J. (1998) Reedbed management and breeding bitterns Botaurus stellaris in the UK. Biol. Conserv. 86: 257-266.

Van der Putten, W. H. (1997) Die-back of Phragmites australis in European wetlands: an overview of the European Research Programme on Reed Die-back and progression (1993-1994). Aquat. Bot. 59: 263-275.

Voisin, C. (1991) The Herons of Europe. London: Poyser.

M. CLAUDIA ADAMO, LUCA PUGLISI* and N. EMILIO BALDACCINI

Dipartimento di Etologia, Ecologia ed Evoluzione, Università di Pisa, via Volta 6, 56126 Pisa, Italy

*Author for correspondence. e-mail: lpuglisi@discau.unipi.it

Received 21 May 2003; revision accepted 7 April 2004 